\title{
Hylid frogs from Mount Ayanganna, Guyana: new species, redescriptions, and distributional records
}

\author{
Ross D. MacCulloch and Amy Lathrop \\ Centre for Biodiversity and Conservation Biology, Royal Ontario Museum, 100 Queen's Park, Toronto, \\ Ontario M5S 2C6, Canada. E-mails: rossm@rom.on.ca, amyl@rom.on.ca.
}

\begin{abstract}
Hylid frogs from Mount Ayanganna, Guyana: new species, redescriptions, and distributional records. A new species of Osteocephalus, one species of Hyla, three species of Hypsiboas and one of Myersiohyla were collected on Mount Ayanganna, a sandstone Guiana Shield tepui. Hyla warreni, Hypsiboas roraima, H. sibleszi, Myersiohyla kanaima and the new Osteocephalus were collected in high-tepui forest at $1500 \mathrm{~m}$ elevation, while Hypsiboas lemai, H. roraima and M. kanaima were also collected in lower montane forest at $870 \mathrm{~m}$. Supplementary descriptions of adults of all species of Hyla, Hypsiboas and Myersiohyla based on the newly collected specimens are provided. Tadpoles of $M$. kanaima are described. The specimens from Ayanganna represent significant distributional records for several species. This is the first record of Osteocephalus as a member of the Guiana Shield high-tepui herpetofauna.
\end{abstract}

Keywords: Anura, Hylidae, Osteocephalus phasmatus sp. nov., Hyla warreni, Hypsiboas lemai, Hypsiboas roraima, Hypsiboas sibleszi, Myersiohyla kanaima, tadpoles, Guyana, tepuis.

\section{Introduction}

The Guiana Shield region of northeastern South America, defined in Hoogmoed (1979a), contains a variety of habitats, including the very interesting tepui highlands. The region is home to many species of hylid frogs. Knowledge of the hylid fauna of the tepui highlands is poor, and few data are available from the eastern highlands (Rivero 1972, Hoogmoed 1979a, b,

Received 9 September 2004.

Accepted 22 March 2005.

Distributed October 2005.
Ayarzagüena et al. 1992a, Duellman and Hoogmoed 1992, Gorzula 1992, Duellman 1997, Gorzula and Señaris 1999, MacCulloch and Lathrop 2002).

Mount Ayanganna, Guyana, is a sandstone tepui, one of the easternmost tepuis in the highlands of the Guiana Shield. A recent collection from Mt. Ayanganna included a number of hylid frogs. Data on the genus Stefania from Ayanganna were provided by MacCulloch and Lathrop (2002). Herein we present data on one species of Hyla, three species of Hypsiboas and one species of Myersiohyla and describe a new species of Osteocephalus. 


\section{Material and Methods}

The topography of Mount Ayanganna consists of a series of "steps" - steep inclines alternating with relatively flat plateaus. Most collecting activities were concentrated on the northeast plateau of Mt. Ayanganna $\left(05^{\circ} 24^{\prime} \mathrm{N}\right.$, $59^{\circ} 57^{\prime} \mathrm{W}$ ), at an elevation of $1490-1550 \mathrm{~m}$ in wet low evergreen high-tepui forest, dominated by Bonnetia roraimae, Schefflera, Clusia and Ilex (Huber et al. 1995), with large terrestrial bromeliads (Brocchinia). The northeast plateau is moist and humid, with a small intermittent stream.

Some specimens were collected at the base of the mountain $\left(05^{\circ} 25^{\prime} \mathrm{N}, 59^{\circ} 58^{\prime} \mathrm{W}, 870 \mathrm{~m}\right)$, in lower montane forest. These specimens were collected in, or adjacent to, two streams, one less than $1 \mathrm{~m}$ wide, with little flow and numerous lentic pools, the other about $1.5 \mathrm{~m}$ wide and fastflowing. All specimens were collected by hand and many were photographed live. Specimens were euthanized using a mixture of clove oil, ethanol and water. Specimens were fixed in $10 \%$ formalin; tissue (liver) was removed and preserved in $95 \%$ ethanol.

Coordinates and elevations were determined using a Global Positioning System (GPS). All measurements of specimens were made using digital calipers. Interdigital webbing is described using the formula of Lescure (1975) and Myers and Duellman (1982), as refined by Savage and Heyer (1997). Nomenclature follows Faivovich et al. (2005). Tadpole stages are those of Gosner (1960); oral disc characters follow Altig and McDiarmid (1999). Institutional acronyms follow Leviton et al. (1985). Specimens are in the collections of the Royal Ontario Museum (ROM) or the Centre for the Study of Biological Diversity at the University of Guyana (CSBD).

\section{Results}

A new species of Osteocephalus, one species of Hyla, three species of Hypsiboas and one species of Myersiohyla were collected at
Mount Ayanganna. These species are treated below. Specimens examined are listed in the Appendix I.

\section{Osteocephalus Steindacher, 1862}

Following Trueb's (1970) redefinition of Osteocephalus, Trueb and Duellman (1971) placed five species in the genus. Since then 16 additional species have been described or removed from synonymy (Henle 1981, Martins and Cardoso 1987, Ayarzagüena et al. 1992a, Duellman and Mendelson 1995, Jungfer and Schiesari 1995, Gorzula and Señaris 1996, Ron and Pramuk 1999, Jungfer et al. 2000, Jungfer and Lehr 2001, Smith and Noonan 2001, Jungfer and Hödl 2002, Lynch 2002), and one synonymised (Jungfer and Hödl 2002). The six species in the $O$. rodriguezi group were removed from Osteocephalus and placed into the genus Tepuihyla by Ayarzagüena et al. (1992b). Trueb and Duellman (1971) listed 20 diagnostic characters for Osteocephalus, and some additional diagnostic character states were provided by Jungfer and Hödl (2002).

Osteocephalus is distributed in forest habitat across northern South America. Although it is not typically a high-elevation genus, some species have been collected in Andean montane forest above $1000 \mathrm{~m} \mathrm{(O.} \mathrm{mutabor,} \mathrm{to} 1100 \mathrm{~m}$; $O$. pearsoni, to $1600 \mathrm{~m}$; O. verruciger, to $1800 \mathrm{~m}$; Trueb and Duellman 1971).

Osteocephalus phasmatus sp. nov. (Figures 1, 2A, 2B and 3)

Holotype: ROM 39481, an adult female collected on the northeast plateau of Mount Ayanganna, Guyana, $\left(05^{\circ} 24^{\prime} \mathrm{N}, 59^{\circ} 57^{\prime} \mathrm{W}\right)$ elevation 1490-1550 m, 27 October 2000, collected by A. Lathrop.

Paratypes: ROM 39482-39485, two adult females and two adult males, same location as holotype, 25 October-1 November 2000, collected by A. Lathrop, C. Cox and R. Edward.

Diagnosis: a medium-large species of 
Osteocephalus characterised by marked sexual dimorphism, tympanum approximately $50 \%$ eye diameter, largest finger disc larger than tympanum diameter, low frontoparietal ridges, reduced foot webbing, tubercle at base of penultimate phalange of Finger IV single, and high-elevation Guiana Shield habitat.

The following suite of characters places the new species in the genus Osteocephalus: female much larger than male; head slightly longer than wide, well-ossified, exostosed; Finger I shorter than Finger II; vocal sacs paired; dorsal skin tuberculate in males, smooth in females; tympanum prominent; hand and foot webbing moderate; outer metatarsal tubercle small, indistinct; tarsal fold absent; palpebrum not reticulated; pupil horizontal (Trueb and Duellman 1971, Jungfer and Hödl 2002).

Of the other hylid genera found in the Guiana Shield region, Tepuihyla has much less hand and foot webbing and the outer metatarsal tubercle is distinct; in Stefania the first finger is longer than the second; in Hyla, Hypsiboas and Myersiohyla the vocal sac is single, subgular.

When compared with other species of Osteocephalus from the Guiana Shield region, $O$. phasmatus differs from $O$. buckleyi by having smooth flank skin (areolate in O. buckleyi), dorsal skin with uniformly-sized spinose tubercles in males (tubercles blunt, varying in size), low cephalic crests (absent), tympanum approximately $50 \%$ eye diameter $(75 \%)$, distal subarticular tubercle on fourth finger single (bifid), foot webbing never reaching the ultimate phalange (reaches base of ultimate phalange of some toes), dorsal color pattern not elaborate (very mottled, with middorsal light stripe in large individuals), and high-elevation habitat (up to $700 \mathrm{~m})$.

Osteocephalus phasmatus differs from $O$. cabrerai by having spinose tubercles (wart-like in O. cabrerai), low cephalic crests (absent), disc on Finger III larger than tympanum diameter (half of tympanum diameter), tympanum approximately $50 \%$ eye diameter $(75 \%)$, foot webbing never reaching the ultimate phalange (reaches ultimate phalange of some toes), color pattern not elaborate (brilliant black and yellow).

Osteocephalus phasmatus differs from $O$. exophthalmus by larger size (34 mm adult male in O. exophthalmus), low cephalic ridges (ridges absent), axillary membrane present (absent), palmar tubercle bifid (single), hand webbing does not reach antepenultimate phalange of any finger (reaches antepenultimate phalanges), largest finger disc larger than tympanum diameter ( $86 \%$ of tympanum diameter), and highelevation habitat (585 m).

Osteocephalus phasmatus differs from $O$. leprieurii by having several enlarged tubercles in tympanic region (small tubercles, even in larger individuals of $O$. leprieurii), low cephalic crests (absent), axillary membrane present (absent), tympanum approximately 50\% eye diameter $(75 \%)$, supernumerary tubercles on the proximal phalanges of toes 1 and 2 (absent), foot webbing never reaching the ultimate phalange (reaches base of ultimate phalange of some toes), distal tubercle under fourth finger single (bifid), dorsum with scattered dark brown flecks or occasionally mottled (transverse dark brown bars), venter and flanks with dark brown reticulations (immaculate), and high-elevation habitat $(<900 \mathrm{~m})$.

Osteocephalus phasmatus differs from $O$. oophagus by the presence of spinose dorsal tubercles in males (a few non-spinose tubercles in O. oophagus), frontoparietal ridges present, low (absent), axillary membrane extending half the length of humerus (one-fifth), largest finger disc larger than tympanum $(80 \%$ of tympanum diameter), third toe longer than fifth (fifth longer than third), and high elevation habitat (low elevation).

Osteocephalus phasmatus differs from $O$. taurinus by having low cephalic ridges (ridges prominent in O. taurinus), dorsal tubercles in males small, dense, spinose (larger, more widely separated), tympanum approximately $50 \%$ eye diameter $(75 \%)$, foot webbing never reaching the ultimate phalange (reaches ultimate phalange of some toes), webbing does not reach the base of 
antepenultimate phalange of third finger (midway on antepenultimate phalange), hand webbing smooth (granular), distal tubercle under fourth finger single, round (bifid), high-elevation habitat (up to $1030 \mathrm{~m}$ ), color pattern.

A summary of characters for identification of Guiana Shield Osteocephalus is in Table 1. All other known species of Osteocephalus (O. deridens, $O$. elkejungingerae, $O$. fuscifacies, $O$. heyeri, O. leoniae, O. mutabor, O. pearsoni, O. planiceps, O. subtilis, O. verruciger, O. yasuni) do not occur in the Guiana region and are found at considerable distance to the west or south.

Description of holotype: Adult female, SVL $62.1 \mathrm{~mm}$, head width $96 \%$ of head length, snout rounded in dorsal profile, slightly projecting in lateral profile, snout length subequal to diameter of eye. Canthus rostralis distinct, concave; loreal region concave, sloping to lip. Nostrils slightly protruberant, directed laterally. Internarial distance about $70 \%$ interorbital distance, internarial region flat or slightly concave. Interorbital distance approximately equal to upper eyelid width. Upper eyelid smooth. Frontoparietal ridges present, low. Temporal region sloping outward ventrally. Tympanum distinct, round, $54 \%$ eye diameter, separated from the eye by a distance equal to
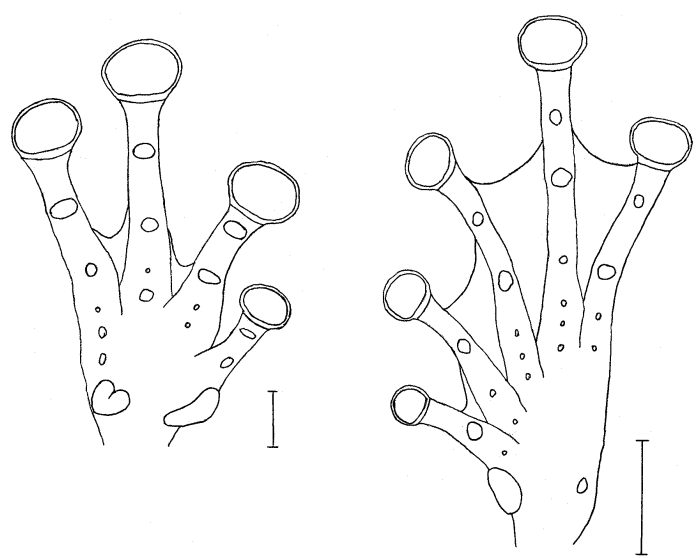

Figure 1 - Palm and sole of Osteocephalus phasmatus. Scale bars $=5 \mathrm{~mm}$

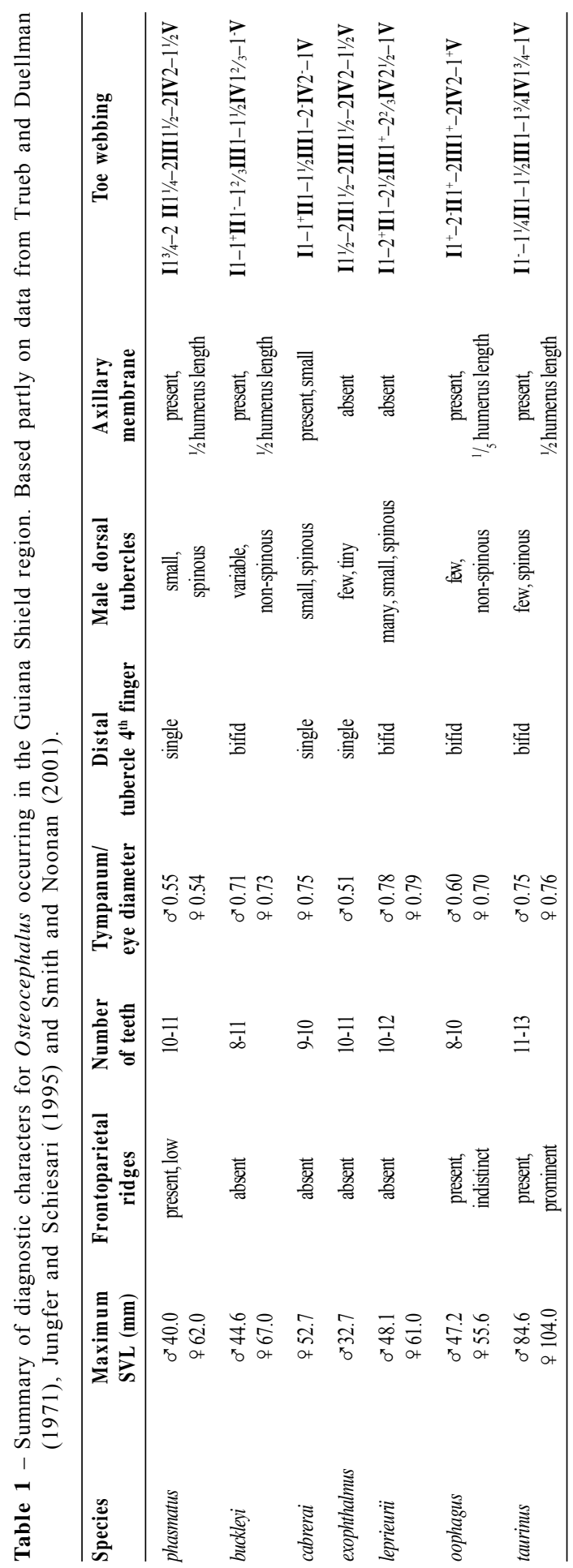

Phyllomedusa - 4(1), October 2005 

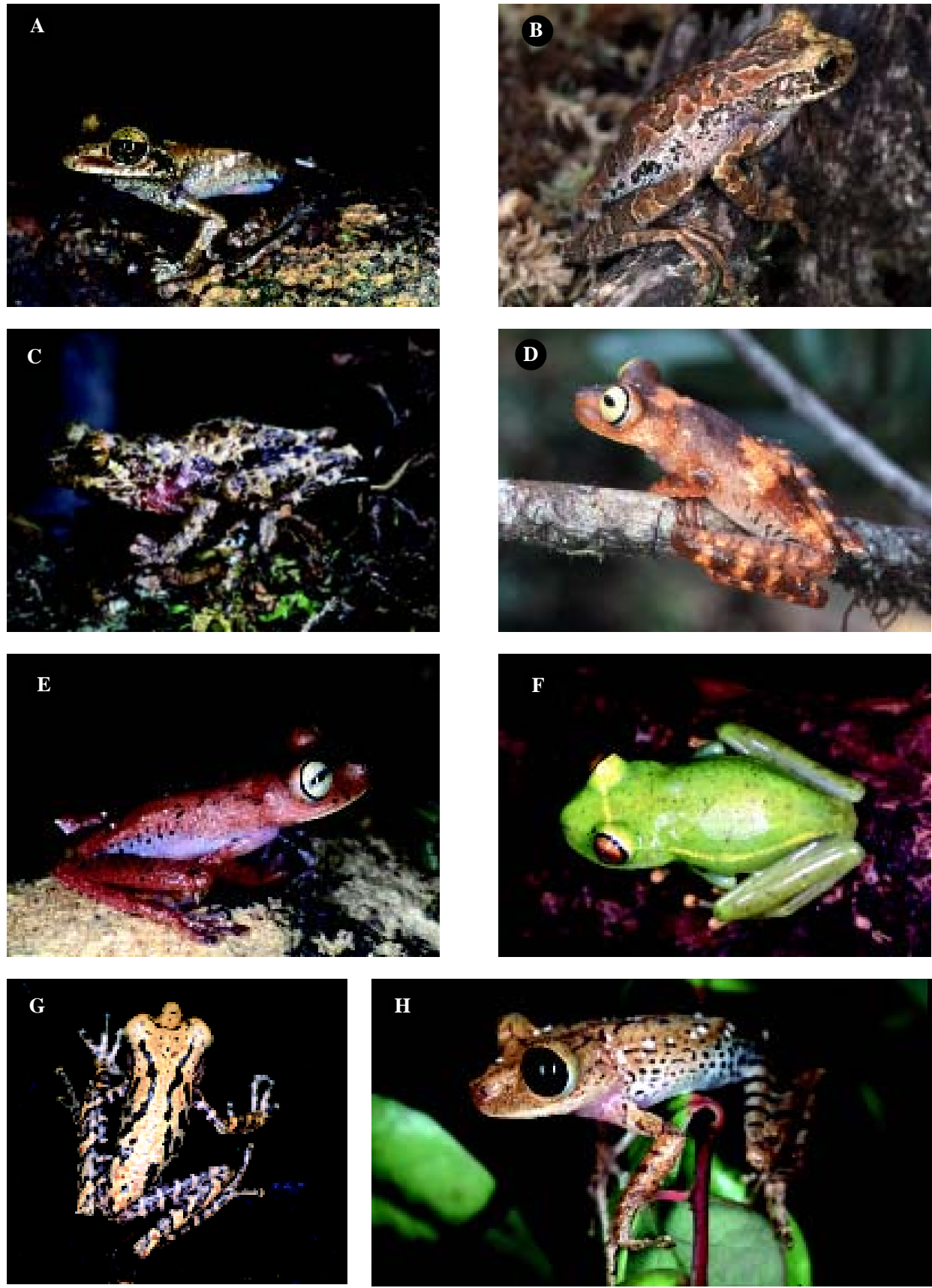

Figure 2 - A. Osteocephalus phasmatus ROM 39485, o $40 \mathrm{~mm} \mathrm{SVL;} \mathrm{B.} \mathrm{Osteocephalus} \mathrm{phasmatus} \mathrm{ROM} 39482$, ㅇ $61 \mathrm{~mm} \mathrm{SVL}$; C. Hyla warreni, ROM 39494, ㅇ $40 \mathrm{~mm} \mathrm{SVL}$; D. Hypsiboas roraima, ROM 39619, + $41 \mathrm{~mm} \mathrm{SVL}$; E. Hypsiboas roraima, ROM 39603, ơ $38 \mathrm{~mm} \mathrm{SVL}$; F. Hypsiboas sibleszi, ROM 39565, $\sigma^{\star} 34 \mathrm{~mm}$ SVL; G. Myersiohyla kanaima, ROM 39592, ㅇ $44 \mathrm{~mm}$ SVL; H. Myersiohyla kanaima, ROM 39587, if $46 \mathrm{~mm} \mathrm{SVL}$. 
$40 \%$ of eye diameter. Supratympanic fold distinct, extending from posterior corner of eye to above insertion of forelimb, obscuring upper margin of tympanum. Loreal and tympanic regions with few rounded tubercles.

Choanae large, oval. Prevomerine processes angular, transverse between and posterior to choanae, not in contact, bearing 10 teeth each. Tongue large, round. Palpebral membrane not reticulated, with a dark brown band along upper rim.

Skin on dorsum and flanks smooth. Venter and posterior surface of thighs granular. Axillary membrane extending to midpoint of upper arm. Anal opening directed posteriorly at upper level of thighs.

Palmar tubercle large, distinct, bifid; thenar tubercle large, distinct, elongate. Subarticular tubercles large, distinct, single, round, distal tubercle on the third and fourth fingers laterally expanded. Supernumerary tubercles on palm and bases of fingers small, round. Relative finger lengths $3>4>2>1$. Finger webbing formula II $2^{-}-3$ III $2 \frac{3}{4}-2^{1 / 2}$ IV. Finger discs large, broader than penultimate phalange, smallest on first, the others subequal. Largest disc slightly larger than tympanum (Figure 1).

Inner metatarsal tubercle large, oval, distinct; outer metatarsal tubercle small, indistinct. Subarticular tubercles single, round, distinct. Supernumerary tubercles on soles and toes round, distinct. Relative length of toes $4>3>5$ $>2>1$. Toe webbing formula I $1 \frac{3 / 4}{4}-2^{+}$II $1 \frac{1 / 4}{4}-2^{+}$ III $1 \frac{1 / 4}{4}-2 \frac{1 / 4}{4}$ V $2^{+}-1$ V. Toe discs oval, broader than penultimate phalange, the first smallest, the others subequal, equal to finger discs. Tibia length 58\% SVL; heels overlap when hindlimbs are adpressed perpendicularly to sagittal plane of body. Tibiotarsal articulation reaches tip of snout when hindlimb is extended anteriorly (Figure 1).

Color in life: Dorsum medium brown with scattered black flecks. Tympanic region and upper lip dark brown. Flanks and groin white with dark brown reticulations. Rear of thigh brown with small white spots. Venter white with dark brown reticulations on throat and chest. Palms and soles with scattered melanophores. Long limb bones green. Iris gold with dense black reticulations and a median horizontal brown bar (Figure 2A). Body color in preservative similar to that in life.

Variation: The species has marked sexual dimorphism (two males $40 \mathrm{~mm}$ SVL; three females $61-62 \mathrm{~mm}$ SVL). Head width $91 \%$ of head length in males, 96-115\% in females. Tympanum diameter 54-55\% eye diameter. Prevomerine processes curved or angular, teeth 10-11. Upper eyelid smooth in females, tubercular in males. Dorsal skin smooth in females, with scattered tubercles in one individual (ROM 39483). Dorsum with small uniform spinous tubercles in males. Loreal and tympanic regions with a few rounded tubercles in females, and with spinous tubercles, larger than those on the back, in

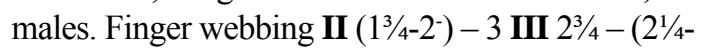
$\left.2^{3 / 4}\right)$ IV. Tibia length $54-58 \%$ SVL. Toe webbing I

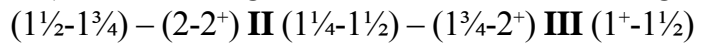
$-\left(2-2 \frac{1}{4}\right)$ IV $\left(2-2^{+}\right)-\left(1-1^{+}\right) \mathbf{V}$. Webbing slightly more extensive in females than in males. Lateral expansion of distal tubercle on Fingers III and IV reduced in some individuals of both sexes.

Dorsal color medium brown to greyish brown with variable darker markings ranging from scattered flecks to large blotches; in one female the dorsal blotches have pale margins, giving a lichen-like appearance (Figures 2B and 3). Tympanic region and upper lip usually dark brown, with a white patch below eye in one female.

Vocal slits at the angle of the jaw. Vocal sacs paired, posterolateral. Brown nuptial pads present on inner side of Finger I. These pads are visible only at $25 \mathrm{X}$ magnification; at lower magnification they are indistinguishable from pigmentation. There are no subdigital or gular nuptial excrescences, as in O. leprieurii (Jungfer and Hödl 2002). All females have numerous bicolored (black and white) eggs, $1.5-1.7 \mathrm{~mm}$ in diameter.

Etymology: The specific epithet is from the Greek "phasma", meaning "phantom". It refers 

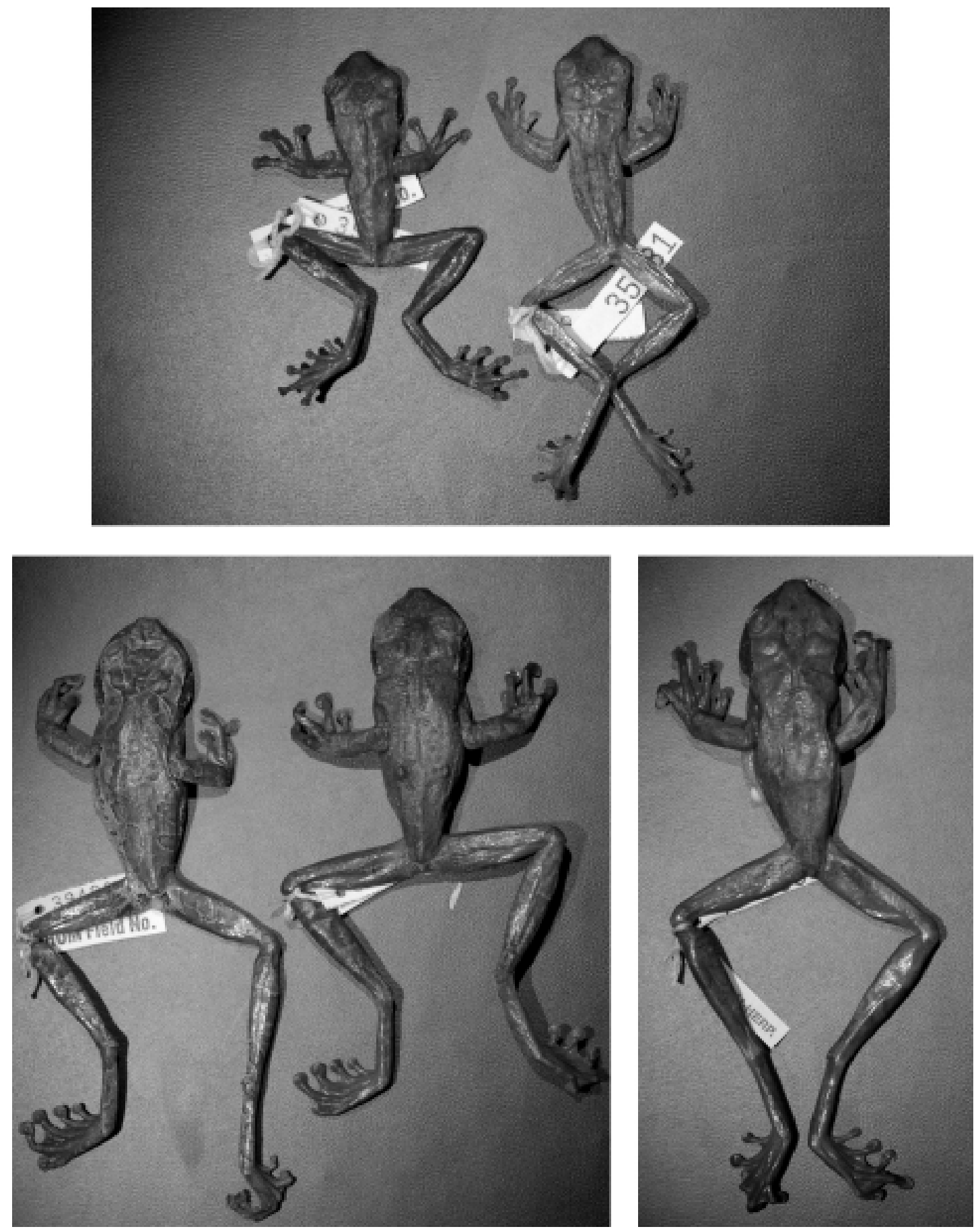

Figure 3 - Color pattern variation in two males (top) and three females (bottom) of Osteocephalus phasmatus.

Phyllomedusa - 4(1), October 2005 
to the species' ghostlike appearance in its misty cloud forest habitat.

\section{Hyla warreni Duellman and Hoogmoed, 1992} (Figures 2C and 4)

Hyla warreni Duellman and Hoogmoed 1992: 10, Faivovich et al. 2005: 41.

This species was described from two females collected at $1480 \mathrm{~m}$ on Mount Roraima. At Mt. Ayanganna 10 individuals (5 males, 5 females) were collected at 1490-1550 m. The specimens collected at Ayanganna expand the description in Duellman and Hoogmoed (1992) as follows: SVL males $32.2-39.3 \mathrm{~mm}$, females $37.3-42.1$ $\mathrm{mm}$; head length $97 \%$ of width in males, $98 \%$ in females; tympanum diameter $0.4-0.5$ of eye diameter; disc of Finger III equal to or larger than tympanum; distal subarticular tubercle on Finger III single, on Finger IV bifid or single;

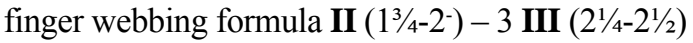
$-2 \frac{1}{2} \mathbf{I V}$; tibia length $55 \%$ of SVL in males, $57 \%$ in females; heels overlap considerably when hindlimbs are flexed perpendicularly to the sagittal plane of the body; toe webbing formula $\mathbf{I}$ $2^{-}-\left(2^{1 / 4}-2^{1 / 2}\right)$ II $\left(1 \frac{1}{4}-1 \frac{1}{2}\right)-\left(2^{1 / 4}-2^{1 / 2}\right)$ III $\left(1^{+}-1 \frac{1 / 4}{4}-\right.$ $\left(2^{1 / 4}-2^{3 / 4}\right)$ IV $2^{1 / 4}-\left(1^{+}-1^{1 / 4}\right)$ V. Dorsal skin smooth, with distinct pustules in some individuals. Most vomerine odontophores transverse, widely separated, each bearing 4-7 teeth; oblique or slightly arched in two individuals; transverse but longer, almost in contact, each with 11 teeth in one individual. Small black eggs $(0.3 \mathrm{~mm}$ diameter) present in two females; no enlarged ova in the others.

Color in life: Dorsum ground color greenishgrey with medium brown blotches outlined in darker brown; fine dark brown or black reticulations between blotches on back. Dorsal dark blotches joined to form two irregular longitudinal stripes in one female. Dorsal pattern of diffuse brown reticulations and scattered dark brown spots on the ground color in two males. Axilla and flanks reddish-brown with dark brown blotches. Posterior thigh surface uniform medium brown with small white spots. Venter white

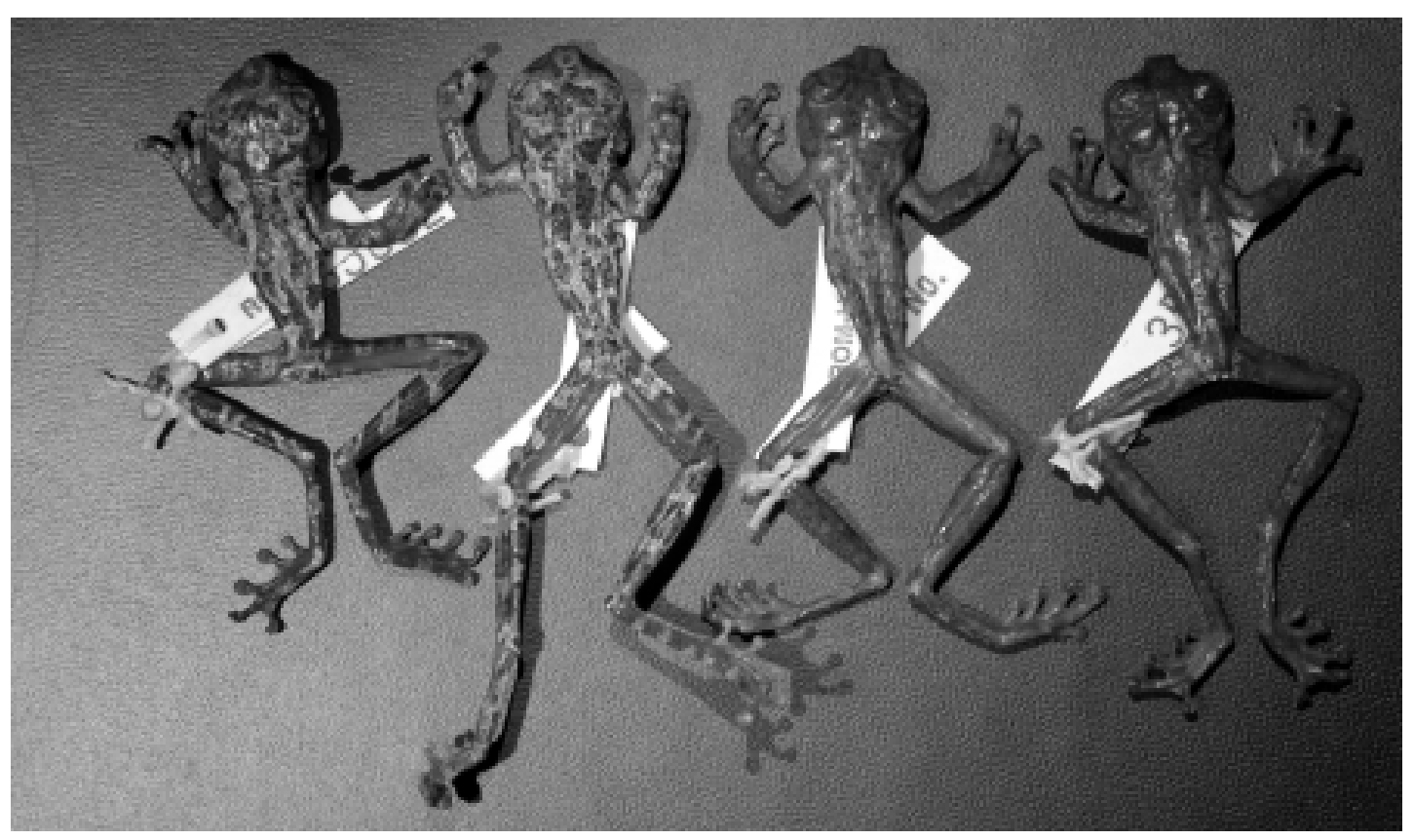

Figure 4 - Color pattern variation in Hyla warreni from Mount Ayanganna. 
with reddish-brown mottling on throat and chest, changing to small spots on belly. Underside of limbs white with reddish-brown wash. Iris gold to pale green with fine radiating black reticulations. Palpebral membrane not reticulated, upper edge with a broad black band containing tiny white specks. In preservative the dorsal background is cream to grey and the reddish brown color is brown. (Figures $2 \mathrm{C}$ and 4).

The specimens collected at Ayanganna differ from those from Roraima as follows: females 37.3 - $42.1 \mathrm{~mm}$ SVL (Roraima females 32.9 - 36.2); dorsal skin with pustules in some individuals (smooth); tympanum $0.4-0.5$ of eye diameter (0.34); distal subarticular tubercles on Fingers III and IV single (bifid). These differences are slight and within the range of interpopulation variation.

Hyla warreni has previously been reported from Mt. Roraima. The specimens from Mt. Ayanganna extend the species' range eastward by some $80 \mathrm{~km}$.

\section{Hypsiboas lemai (Rivero, 1972) (Figure 5)}

Hyla lemai Rivero 1972: 183, Hoogmoed 1979b: 32, Duellman 1997: 16, Barrio 1998: 31, Gorzula and Señaris 1999: 88.
Hypsiboas lemai Faivovich et al. 2005 : 87.

Rivero (1972) described this species from a single specimen collected at La Escalera, Venezuela. Duellman (1997) provided further information on color and habitat from additional specimens from La Escalera. Five specimens, all calling males, were collected adjacent to a fastflowing stream in lower montane forest at the base of Mt. Ayanganna, elevation $870 \mathrm{~m}$. The specimens from Ayanganna expand the descriptions in Rivero (1972) and Duellman (1997), as follows: male SVL 28.5-31.8 mm; tibia length half of SVL; eye diameter slightly greater than eye-nostril distance; eye-tympanum distance equal to tympanum diameter; vomerine processes arched, each bearing 7-9 teeth (10/11 in one individual); heels overlapping very slightly when hindlimbs are flexed perpendicularly to sagittal plane of body; finger webbing II $2-3$ III $2 \frac{3}{4}-\left(2 \frac{1}{4}-2^{1 / 2}\right)$ IV; toe webbing I $1 \frac{1}{4}-$

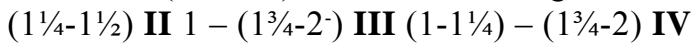
$\left(1 \frac{3}{4}-2\right)-1 \mathrm{~V}$.

Color in life: dorsum medium brown, with dense melanophores on back and upper surfaces of limbs, extending onto fingers III and IV, and toes IV and V; diffuse black interorbital and canthal lines and a faint black supratympanic line. Palpebral membrane unpigmented except for a thin dark brown line along upper edge. Limbs

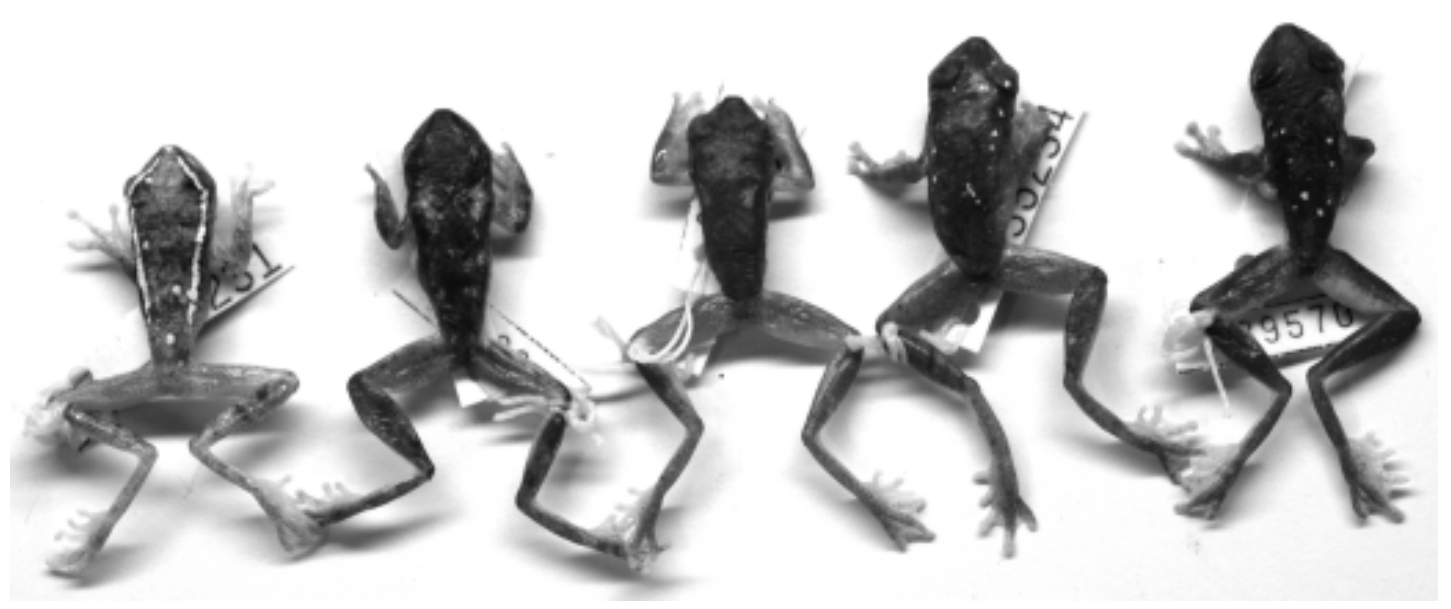

Figure 5 - Color pattern variation in Hypsiboas lemai from Mount Ayanganna. 
with dark brown crossbands. Ventral surfaces white. Diffuse whitish patches present on dorsum and limbs of one individual, similar to the photograph in Rivero (1972, p. 189). Scattered white spots present on dorsum in three specimens; one of these also has white dorsolateral lines extending almost to the groin, and anteriorly to the nostrils. In preservative the dorsum is dark brown (Figure 5).

The specimens of Hypsiboas lemai from Ayanganna do not differ significantly from those described by Rivero (1972) and Duellman (1997), although they are darker dorsally than the photograph in Duellman (1997, p. 10). The pattern of dorsolateral white lines has never been previously reported in this species, but this pattern is not uncommon in Hypsiboas.

Hypsiboas lemai has been reported from La Escalera (Rivero 1972, Duellman 1997), Auyántepui and Mount Roraima (Hoogmoed 1979b). The specimens from Ayanganna extend the species' range eastward by about $80 \mathrm{~km}$. Although Rivero (1972) and Duellman (1997) collected H. lemai at $1300-1400 \mathrm{~m}$ in La Escalera, it was found only at $870 \mathrm{~m}$ on Ayanganna, despite intensive collecting at 1490-1550 $\mathrm{m}$. The lack of permanent stream habitat may preclude its occurrence at 1490-1550 m; H. lemai has been collected exclusively in streamside habitat by Rivero (1972) and Duellman (1997).

\section{Hypsiboas roraima \\ (Duellman and Hoogmoed, 1992) \\ (Figures 2D, 2E and 6)}

Hyla roraima Duellman and Hoogmoed 1992: 6.

Hypsiboas roraima Faivovich et al. 2005: 87.

Hypsiboas roraima was described from three females collected at 1430-1480 m on Mount Roraima. At Mt. Ayanganna 29 specimens (18 females, 11 males) were collected at 1490-1550 $\mathrm{m}$, with three additional males collected at $870 \mathrm{~m}$. The specimens from Ayanganna expand the description in Duellman and Hoogmoed (1992) as follows: SVL males $36.5-40.8 \mathrm{~mm}$, females
$37.5-45.8 \mathrm{~mm}$; head width $94 \%$ of head length in males, $96 \%$ in females; tympanum diameter $45 \%$ of eye diameter in males, $43 \%$ in females; disc of Finger III slightly greater than tympanum diameter; distal subarticular tubercle of Finger IV bifid; tibia length $53 \%$ of SVL in males, $54 \%$ in females; heels strongly overlap when hindlimbs are flexed perpendicularly to sagittal plane of body; toe webbing formula I $\left(2^{1 / 1} 4^{-1 / 2}\right)-2^{1 / 2}$ II $1 \frac{3}{4}$

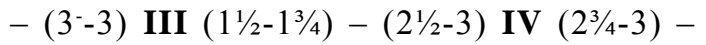
$\left(1 \frac{1}{2}-1 \frac{3}{4}\right) \mathbf{V}$.

Vomerine odontophores angular, abutting or separated medially, most bearing 11-13 teeth, a few individuals with 8 or 9 teeth. All but three adult females exhibited some stage of egg enlargement; eggs are black and white, the largest $2 \mathrm{~mm}$ in diameter.

Color in life: Dorsal ground color medium reddish-brown with a pattern varying between two extremes: the first having four dark brown patches - on top of snout, between orbits, in scapular region, and in sacral region; the second having only a few small scattered dark brown marks. Dark brown middorsal stripe from tip of snout to posterior dorsum present in 12 individuals; usually, but not always, extending to the groin; middorsal stripe never present on individuals with dorsal pattern of dark patches. Color pattern not correlated with sex or size. Scattered dorsal white spots present in some individuals. Limbs with dark brown crossbands, usually most prominent on hindlimbs; crossbands reduced to small dark brown spots in some individuals. Axilla pink, flanks pink with dark brown bars or spots and white spots posteriorly in some individuals. Rear of thigh pale brown with small dark brown spots. Upper lip yellow. Venter white; undersides of forearms, hands, tarsi and feet shading to reddish-brown. A row of dark spots along underside of tarsus and onto toe V. Iris pale green to yellow, pupil horizontal. Palpebral membrane with white reticulations, its upper edge with a brown-andwhite speckled band. In preservative the reddish-brown and pink colors change to tan. (Figures 2D, 2E and 6). 


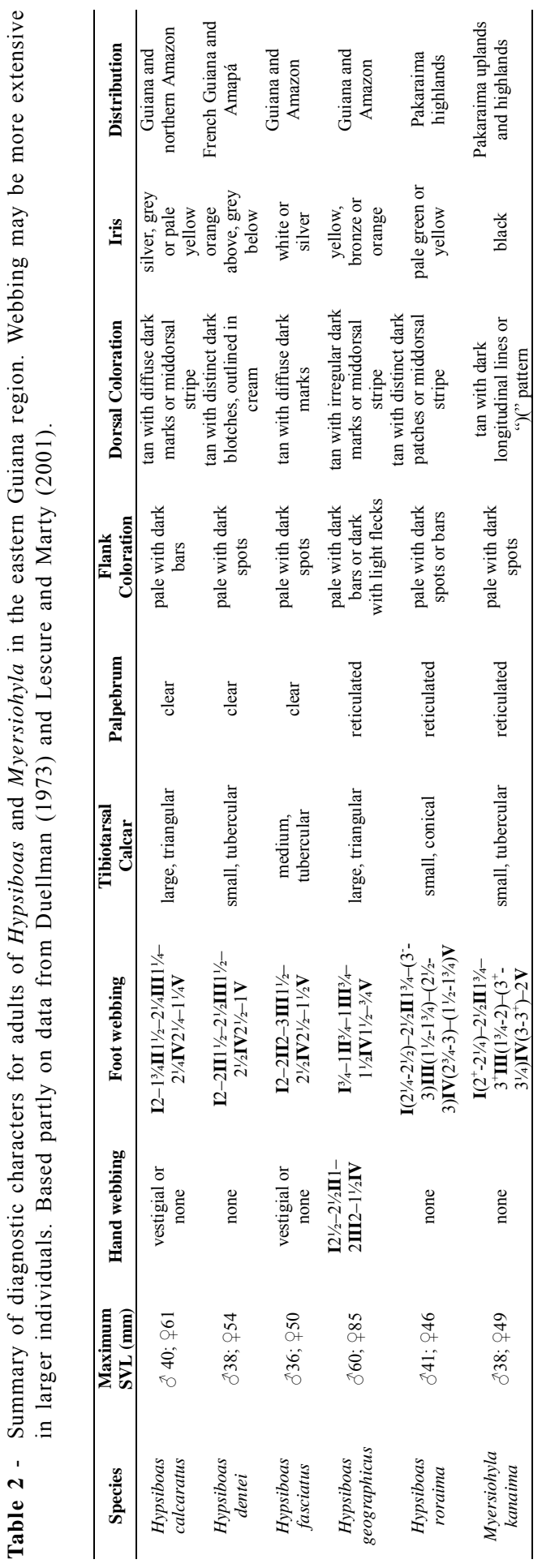

The specimens from Ayanganna differ from those from Roraima (Duellman and Hoogmoed 1992) as follows (specimens from Roraima in parentheses): disc of Finger III slightly greater than tympanum diameter (slightly less); distal subarticular tubercle of Finger IV bifid (laterally expanded); maximum of 13 teeth on odontophores (16). Foot webbing and color pattern also differ slightly between the two locations. The sample from Ayanganna contained numerous specimens of both sexes that exhibit a large range of body size, whereas only three adult females were collected at Roraima. The physical differences between the two samples are minor.

Hypsiboas roraima has previously been reported only from Mt. Roraima. The specimens from Mt. Ayanganna extend the species' range eastward by some $80 \mathrm{~km}$. Hypsiboas roraima can be confused with other hylid frogs in the region. Characters useful for identification of some adult hylids from the Guiana Shield are summarised in Table 2.

\section{Hypsiboas sibleszi (Rivero, 1972) \\ (Figures $2 \mathrm{~F}$ and 7)}

Hyla albomarginata (part) Boulenger 1900: 56, Crawford 1931: 33.

Hyla sibleszi Rivero 1972: 182, Hoogmoed 1979b: 23, Duellman 1997: 19, Barrio 1998: 34, Gorzula and Señaris 1999: 35.

Hypsiboas sibleszi Faivovich et al. 2005: 88.

Rivero (1972) originally described this species from 10 specimens from La Escalera, eastern Venezuela. A redescription of adults based on numerous additional specimens, plus a description of the tadpole, is provided by Hoogmoed (1979b). Duellman (1997) provided further information from additional specimens from La Escalera.

On Mount Ayanganna 15 adults (13 males, two females) were collected. Our sample expands the descriptions in Rivero (1972), Hoogmoed (1979b) and Duellman (1997), as follows: SVL males $31.7-37.7 \mathrm{~mm}$, females $35.2-36.3 \mathrm{~mm}$; head width $97 \%$ of head length in males, $96 \%$ in 

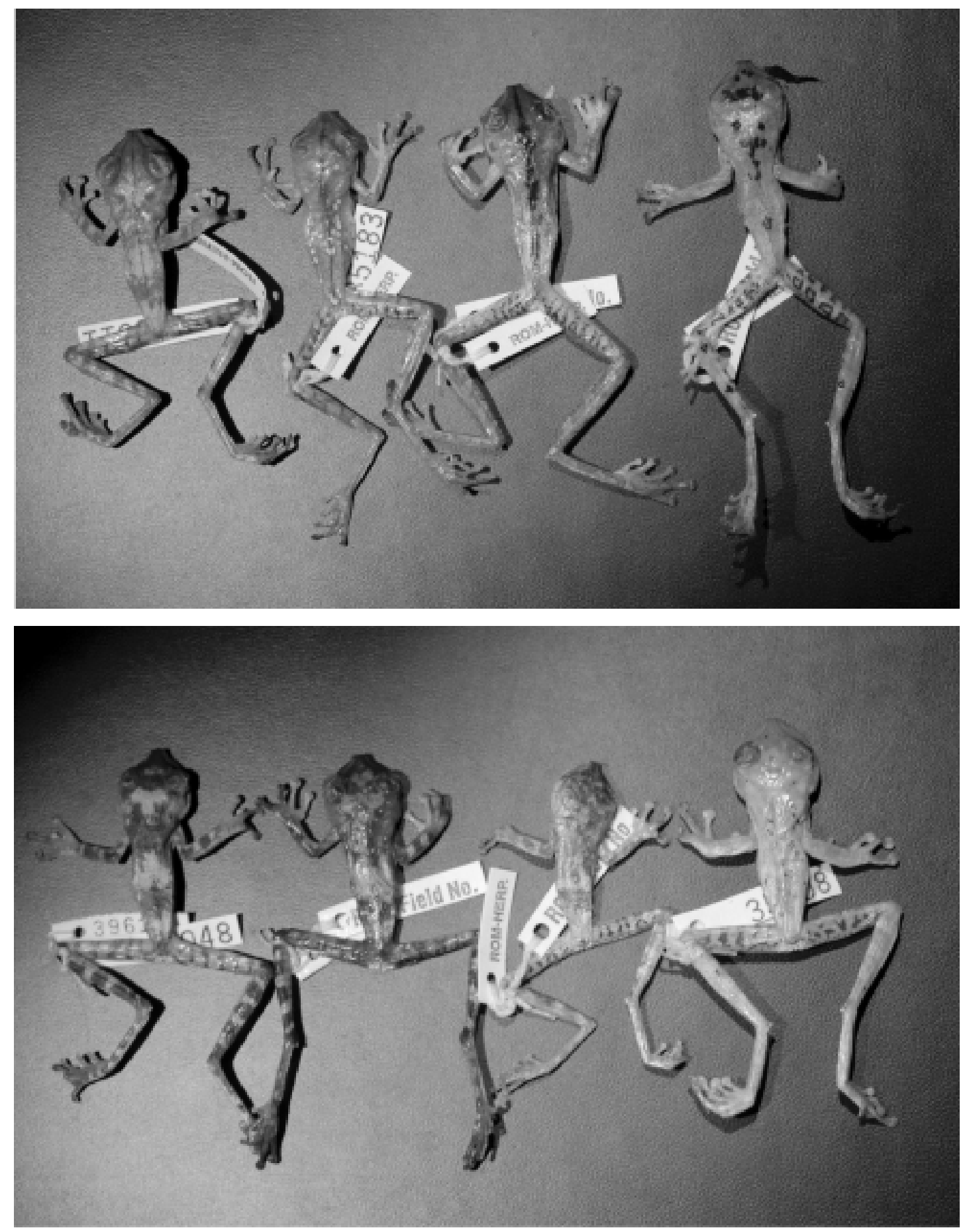

Figure 6 - Color pattern variation in Hypsiboas roraima from Mount Ayanganna. 
females; tympanum diameter $56 \%$ of eye diameter in males, $53 \%$ in females; vomerine teeth 7-11; tibia length $53 \%$ of SVL in both sexes; when hindlimbs are flexed perpendicularly to sagittal plane of body, heels contact or overlap very slightly.

Finger webbing formula II $2-\left(3-3^{+}\right)$III $\left(2^{1 / 2-}\right.$ $\left.2^{3 / 4}\right)-2 \frac{1}{4} \mathbf{I V}$; toe webbing formula I $1 \frac{3}{4}-\left(2-2^{1 / 4}\right)$ II $\left(1^{+}-1 \frac{1}{4}\right)-\left(2-2^{1 / 4}\right)$ III $\left(1^{+}-1 \frac{1 / 4}{4}\right)-\left(2-2^{1 / 4}\right)$ IV $2-\left(1^{+}-\right.$ $\left.1 \frac{1}{4}\right) \mathrm{V}$.

Color in life: Dorsum greenish-yellow at night, green by day. Both sexes have small brown chromatophores of varying intensity on the dorsum and along upper surfaces of limbs, extending onto Toes IV and V, and Finger IV. Diffuse larger dark brown patches, made up of a concentration of minute spots, between orbits, on dorsum or on shanks in some individuals. Minute dark brown spots on the edge of the lower jaw below tympanum and eye, extending anteriorly to form a continuous line along edge of lower jaw in a few individuals. Scattered round white dorsal spots in several individuals. Pale yellow interorbital and dorsolateral lines present in two males. Digital discs and iris orange; limb bones green. In preservative the dorsal ground color is white and the interorbital and dorsolateral lines are barely visible (Figures $2 \mathrm{~F}$ and 7).
The specimens from Ayanganna exhibit no significant differences from those described elsewhere. The sex ratio of the sample from Ayanganna (many more males collected than females) matches that reported by Hoogmoed (1979b) and Duellman (1997). No enlarged eggs were present in the females collected at Mt. Ayanganna.

Hypsiboas sibleszi is a high-elevation "green" species of Hypsiboas, known to breed in rain-fed streams on high mountains, and most specimens have been collected in or above streams or pools (Hoogmoed 1979b). At Ayanganna, specimens were collected from branches of trees or shrubs, although they were not concentrated near permanent water. Interestingly, although collecting efforts at Ayanganna were concentrated on two plateau "steps", at 1490 and $1550 \mathrm{~m}, H$. sibleszi were collected only on the $1550 \mathrm{~m}$ plateau, although there were no apparent differences in habitat between the two levels; both consist of high-elevation cloud forest. The ROM also has a specimen of $H$. sibleszi from Paramakatoi, Guyana $\left(04^{\circ} 42^{\prime} \mathrm{N}, 59^{\circ}\right.$ $47^{\prime} \mathrm{W}$, elevation $800 \mathrm{~m}$ ), a male collected near a stream in high-canopy submontane forest.

Hypsiboas sibleszi has been reported from La Escalera, Chimantá, Auyán and Roraima

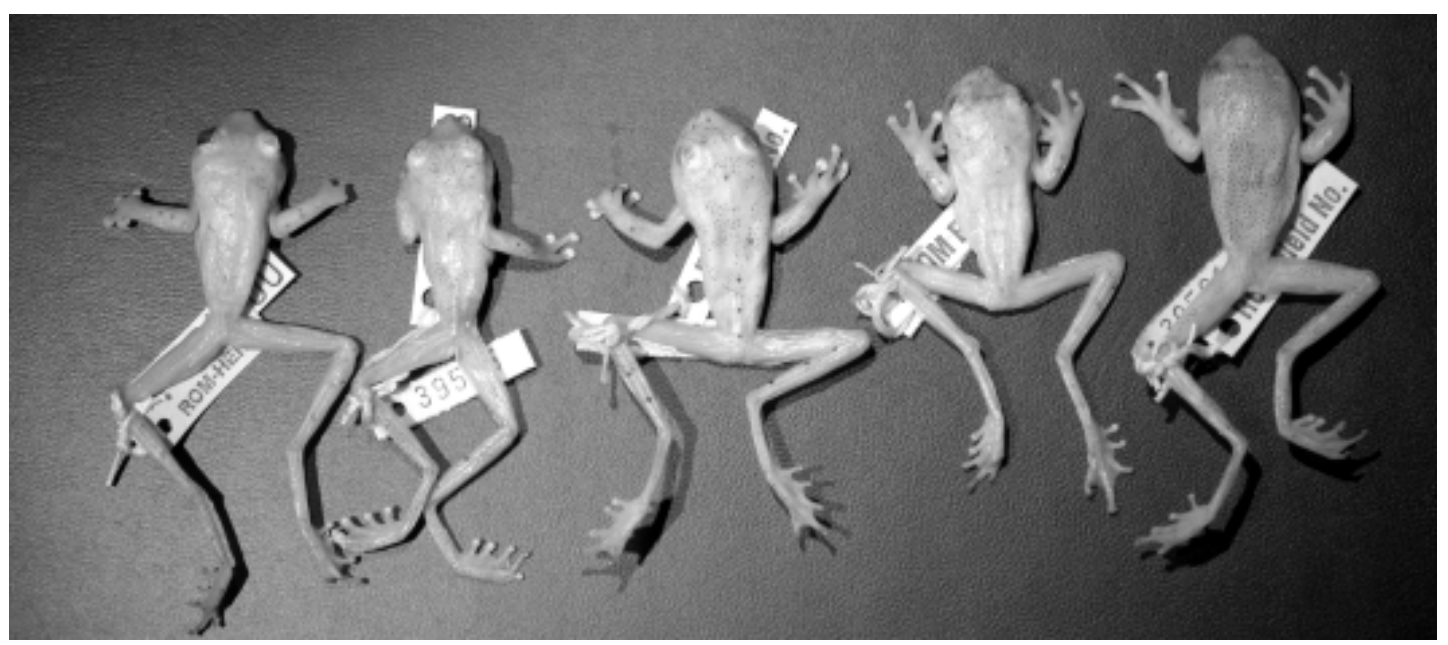

Figure 7 - Color pattern variation in Hypsiboas sibleszi from Mount Ayanganna. 
(Rivero 1972, Hoogmoed 1979b, Duellman 1997, Gorzula and Señaris 1999) at elevations of 900 $1800 \mathrm{~m}$. It has also been collected in northern Amazonas State and western Bolivar State, Venezuela (Gorzula and Señaris 1999, J. C. Señaris, pers. comm.). The specimens from Mount Ayanganna and Paramakatoi extend the species' range substantially to the east and southeast (Figure 11). As proposed by Hoogmoed $(1979 b)$, this species is probably endemic to higher elevations in the Guiana Shield. Hypsiboas sibleszi is a member of the $H$. punctatus group (Faivovich et al., 2005); a key to Guiana region "green" species of Hypsiboas is in Hoogmoed (1979b). Of the H. punctatus group from Guyana in the ROM collections, $H$. sibleszi was the only species collected at Ayanganna and Paramakatoi, whereas $H$. granosus was collected only at lower elevations (Baramita, $07^{\circ} 22^{\prime} \mathrm{N}, 060^{\circ} 29^{\prime} \mathrm{W}, 100 \mathrm{~m}$ and Kurupukari, $04^{\circ} 40^{\prime} \mathrm{N}, 058^{\circ} 39^{\prime} \mathrm{W}, 100 \mathrm{~m}$ ).

\section{Myersiohyla kanaima}

(Goin and Woodley, 1969)

(Figures 2G, 2H, 8, 9 and 10)

Hyla kanaima Goin and Woodley 1969: 136, Duellman and Hoogmoed 1992: 13. 89.

Myersiohyla kanaima Faivovich et al. 2005:

Goin and Woodley (1969) described this species from seven specimens collected at Mount Kanaima, Potaro River, Guyana. Duellman and Hoogmoed (1992) provided a redescription based on three adult females from Mount Roraima. At Mount Ayanganna 23 specimens (4 males, 17 females, 2 juveniles) of M. kanaima were collected both at 1490-1550 m and at the base of the mountain $(870 \mathrm{~m})$. The specimens from Ayanganna conform to previously published descriptions, with the following additions: SVL males $35.1-38.3 \mathrm{~mm}$, females 43.5 - $48.8 \mathrm{~mm}$; interorbital distance equal to upper eyelid width and greater than internasal distance among smaller individuals, but much less than upper eyelid width and equal to internasal distance in larger individuals; tympanum $40 \%$ eye diameter; eye-tympanum distance slightly greater than tympanum diameter; tympanum diameter less than disc of Finger III, equal to disc of Finger IV; Finger IV reaches to base of distal phalange of Finger III; 5-7 very low ulnar tubercles present; heel with two small protruberances; heels overlap slightly when legs are flexed perpendicularly to sagittal plane of body; toe webbing formula I $\left(2^{+}-2^{1 / 4}\right)$

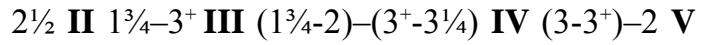
vomerine processes each bearing 12 or 13 teeth. Dorsal skin with scattered tubercles, especially in the interorbital region. Enlarged black-andwhite eggs, $1 \mathrm{~mm}$ in diameter, were present in 13 of the 17 females; the remainder had small white ova.

Color in life: dorsal background golden to medium brown with dark brown or black longitudinal lines. In many individuals the dark lines form a ")(" dorsal pattern, with additional scattered black marks and narrow canthal and interorbital lines; dorsal lines are broken and/or irregular in some individuals. Dark dorsal lines not present in juveniles. Upper eyelid and snout with small black specks. Scattered dorsal white spots present in some individuals. Flanks white to pale yellow with irregular black spots increasing in size posteriorly. Limbs with irregular black crossbands, most pronounced on dorsal surface of thighs, and small spots extending onto outer fingers and toes. Crossbands fade to fine mottling with small white pustules on posterior thigh surface. Axilla white with a reddish wash. Venter white with small brown spots on throat, variable diffuse brown blotches on chest and belly. Palpebral membrane with white reticulations, upper edge with a white band outlined in black. Iris black. In preservative dorsal ground color tan to medium brown. (Figures 2G, 2H and 8).

The specimens from Ayanganna exhibit some differences from those from Kanaima and Roraima (see Appendix I): interorbital distance much less than upper eyelid width (equal or slightly less in specimens from Kanaima and 
Roraima); eye-tympanum distance slightly greater than tympanum diameter (slightly less to nearly equal); tympanum smaller than disc of Finger III (equal); ulnar tubercles present (absent); heels overlap slightly when legs are folded (greatly); vomerine processes with $12-13$ teeth (15 and 19); palpebral membrane reticulated (unpigmented). There are also slight differences in toe webbing. We feel that these differences are within the range of interpopulation variation, and variation may be more obvious because of a larger sample size that includes both sexes and a significant size range.

Tadpoles: Thirty tadpoles (ROM 42389) were collected from lentic pools in a small stream in lower montane forest at the base of Mt. Ayanganna $\left(05^{\circ} 25^{\prime} \mathrm{N}, 59^{\circ} 58^{\prime} \mathrm{W}, 870 \mathrm{~m}\right)$ on 2 November 2000 by A. Lathrop. The tadpoles were identifiable as M. kanaima because two subadults and two recently metamorphosed individuals (Stage 45 ) were collected on the banks of the stream while one in Stage 43 was collected in the stream, along with the other tadpoles. This fortunate series of specimens allows the association of larvae, metamorphs and adults.

This lot contained specimens in Stages 25 $(\mathrm{N}=26), 27(\mathrm{~N}=2)$ and $39(\mathrm{~N}=1)$, plus one aquatic metamorph of Stage 43. Stage 25 individuals vary in total length from 24 to $49 \mathrm{~mm}$. The two individuals in Stage 27 have total lengths of 50 $\mathrm{mm}$ and the individual in Stage 39 has a total length of $58 \mathrm{~mm}$. Snout-vent length is 36-40\% total length and tail height is $21-25 \%$ total length.

The following description is of an individual in Stage 39 (Gosner 1960): Body depressed (width 1.4 times height), oval in dorsal view, chondrocranial elements visible dorsally; eye diameter $43 \%$ of interorbital distance; interorbital distance greater than internarial distance; nares directed dorsolaterally; eye-nostril distance $75 \%$ of nostril-snout tip distance; narial opening reniform in dorsal view; eyes dorsolateral, not visible from below; spiracle sinistral, its base located about midway between venter and dorsum, projecting posterodorsally. Vent tube caudal, dextral, short. Caudal musculature extending to tail tip; myotomes narrow, barely visible; dorsal fin originating on rear of dorsum; dorsal fin $80 \%$ width of musculature at midpoint; ventral fin $50 \%$ width of musculature at midpoint; tail tip acuminate. Tail height $23 \%$ total length (Figure 9).

Mouth ventral, oral disc not emarginate. Teeth long, LTRF 2 (1-2) / 4 [1]. Anterior rows longer than posterior rows. A few short accessory tooth rows in lateral areas of oral disc, oriented at right angles to posterior tooth rows. Accessory rows of this type also occur in Hypsiboas geographicus (Duellman and Lescure 1973). Papillae in a single row, a few submarginal papillae laterally and medially on lower labium, narrow medial gaps in both labia. Papillae tapered, blunt-tipped. Jaw sheaths narrow. Upper jaw sheath almost straight medially, arching laterally; lower jaw sheath V-shaped. Jaw sheaths serrated; serrations partially lost in the individual in Stage 39 (Figure 10).

Color in preservative: body uniformly dark grey-brown, tail musculature and fin with dark grey-brown mottling. Venter opaque, intestine not visible.

Variation: The most obvious ontogenetic change between Stages 27 and 39 is in the mouthparts. Very small A1, A2 and P1 gaps present in Stage 27, P1 gap absent in Stage 39. P4 short with small teeth in Stage 27, increasing in length with longer teeth in later stages. Short accessory lateral tooth rows present only in individuals in Stage 27 or later. Submarginal papillae present in some individuals in Stage 27 or later. Venter transparent in smallest individuals in Stage 25. Some individuals have clear tail fins.

Myersiohyla kanaima has been collected at Mt. Kanaima (700 m elevation) and Mt. Roraima $(1430 \mathrm{~m})$. Mount Ayanganna is approximately midway between these two locations, about 80 $\mathrm{km}$ from either. Tadpoles of M. kanaima resemble those of some other hylids. Characters useful for identification of tadpoles of the region are summarised in Table 3. 


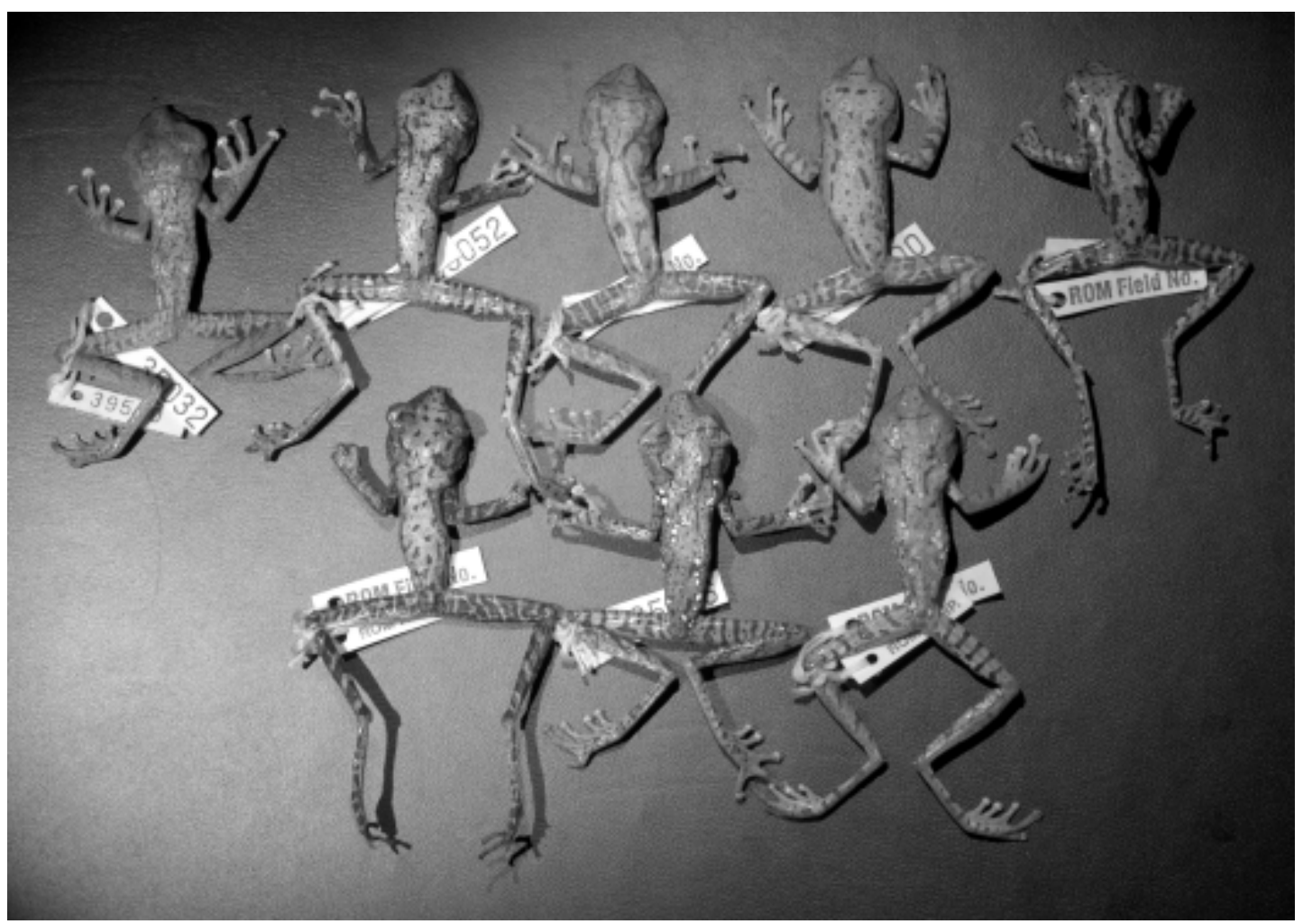

Figure 8 - Color pattern variation in Myersiohyla kanaima from Mount Ayanganna.

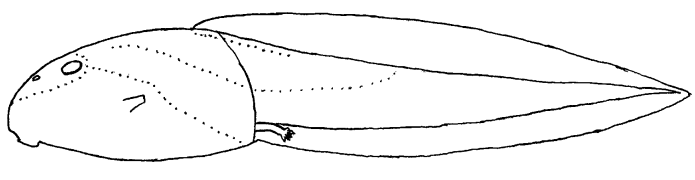

Figure 9 - Tadpole of Myersiohyla kanaima, ROM 42389, Stage 39, total length $58 \mathrm{~mm}$. Scale bar $=10 \mathrm{~mm}$.

\section{Discussion}

Zoogeography: Hyla warreni and Hypsiboas roraima were previously known only from 1400-1500 m on Mount Roraima (Duellman and Hoogmoed 1992). Their occurrence on Mount Ayanganna is not surprising, since the two

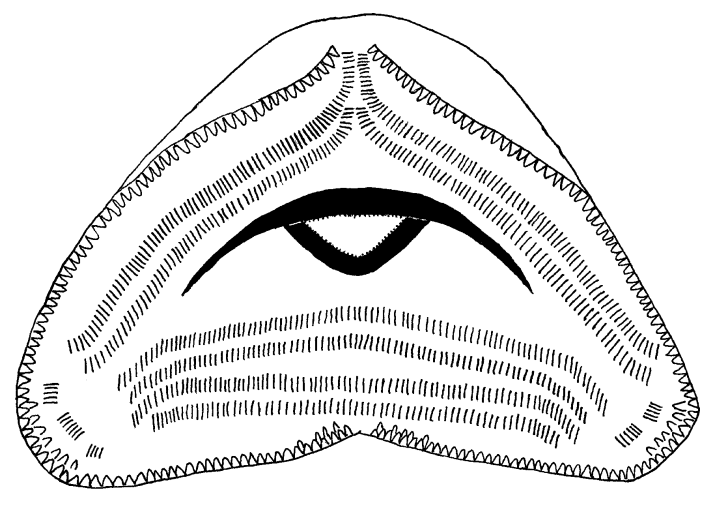

Figure 10 - Mouthparts of tadpole of Myersiohyla kanaima, ROM 42389, Stage 39. Scale bar $=1 \mathrm{~mm}$. 
Table 3 - Characters for identification of some tadpoles of Hypsiboas and Myersiohyla. Based partly on data from Duellman and Lescure (1973), Rodriguez and Duellman (1994) and Lescure and Marty (2001).

\begin{tabular}{|c|c|c|c|c|c|}
\hline Species & Belly Skin & $\begin{array}{l}\text { SVL / Total } \\
\text { Length }\end{array}$ & $\begin{array}{l}\text { Denticle } \\
\text { Rows }\end{array}$ & Papillae & Color \\
\hline $\begin{array}{l}\text { Hypsiboas } \\
\text { calcaratus }\end{array}$ & transparent & $30 \%$ & $2 / 3$ & $\begin{array}{l}\text { single (double in later } \\
\text { stages) }\end{array}$ & $\begin{array}{c}\text { dark brown with } \\
\text { tan and yellow markings }\end{array}$ \\
\hline $\begin{array}{l}\text { Hypsiboas } \\
\text { fasciatus }\end{array}$ & opaque & $33 \%$ & $2 / 3-4$ & $\begin{array}{l}\text { single (double in later } \\
\text { stages) }\end{array}$ & $\begin{array}{l}\text { body dark, tail yellow } \\
\text { with black bands }\end{array}$ \\
\hline $\begin{array}{l}\text { Hypsiboas } \\
\text { geographicus }\end{array}$ & $\begin{array}{l}\text { transparent to stage } \\
40 \text {, then opaque }\end{array}$ & $38 \%$ & $\begin{array}{l}2 / 3 \text { to stage } \\
25 ; \text { then } 3 / 5\end{array}$ & $\begin{array}{l}\text { single (double after } \\
\text { stage } 37 \text { ) }\end{array}$ & uniformly dark \\
\hline $\begin{array}{l}\text { Myersiohyla } \\
\text { kanaima }\end{array}$ & $\begin{array}{l}\text { transparent to stage } \\
25 \text {, then opaque }\end{array}$ & $36-40 \%$ & $\begin{array}{l}2 / 4 \text { (stages } \\
25-39)\end{array}$ & $\begin{array}{l}\text { single (some submarginals } \\
\text { in later stages) }\end{array}$ & body dark, tail mottled \\
\hline
\end{tabular}

mountains are approximately $80 \mathrm{~km}$ apart and support similar habitats. Myersiohyla kanaima has been collected at Mount Kanaima (700 m, Goin and Woodley 1969) and Mount Roraima (1430 m, Duellman and Hoogmoed 1992). Mount Ayanganna is located approximately halfway between these two mountains. Hypsiboas lemai had been reported from several locations in southeastern Venezuela and Mt. Roraima, at 1300-1400 m. Hypsiboas lemai, H. roraima and Myersiohyla kanaima were also collected at $870 \mathrm{~m}$, indicating that these species are not restricted to the highest elevations. Hypsiboas sibleszi is known from numerous locations. The known distributions of these five species, as reported in Goin and Woodley (1969), Rivero (1972), Hoogmoed (1979b), Duellman and Hoogmoed (1992), Duellman (1997), Barrio (1998), Gorzula and Señaris (1999) and this study are shown in Figure 11. We expect that the five species will be found elsewhere in suitable habitat in the Pakaraima region. It will be of interest to determine whether high-elevation species also occur in "upland" areas between the mountains. The Pakaraima region offers many opportunities for study of the zoogeography of the Guiana Shield.

Osteocephalus phasmatus is known only from its type locality on Mt. Ayanganna. This location is at a higher elevation than has been reported for most Osteocephalus, although some Andean species occur up to $1800 \mathrm{~m}$. Donnelly and Myers (1991) collected $O$. taurinus at $1030 \mathrm{~m}$ on Cerro Guaiquinima, Venezuela, but no other Osteocephalus has been reported from the Guiana highlands (Rivero 1972, Duellman and Hoogmoed 1992, Myers and Donnelly 1996, 1997, 2001, Duellman 1997, Barrio 1998, Gorzula and Señaris 1999). Osteocephalus phasmatus represents the first record of the genus as a member of the Guiana Shield hightepui herpetofauna.

Other species: Hypsiboas boans was found in submontane forest habitat north of $\mathrm{Mt}$. Ayanganna at about $800 \mathrm{~m}$. This species is widespread in the region.

Habitat: All specimens from Mount Ayanganna were collected on vegetation above ground level, with the exception of Hypsiboas lemai, which were calling from grassy clumps at the edge of a stream at the base of the mountain $(870 \mathrm{~m})$. This habitat is similar to where other specimens of these species have been collected (Hoogmoed 1979b, Duellman and Hoogmoed 1992). Most specimens were collected in the montane scrub forest which is prevalent at these elevations. Whereas Hyla warreni has been 


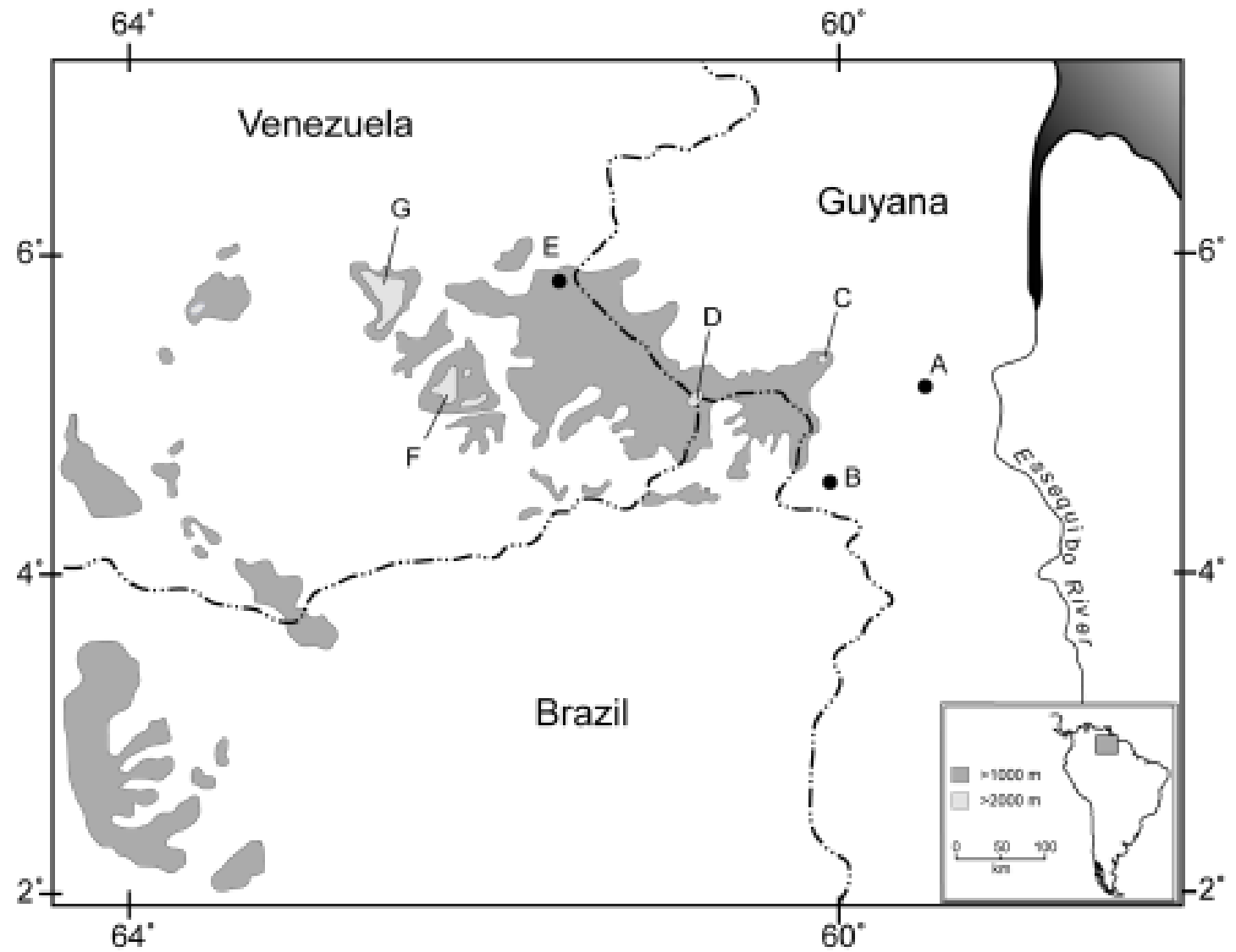

Figure 11 - Distributions of five species of hylid frogs in the eastern highlands of the Guiana Shield. Some species have been reported from more than one locality in the vicinity of the named locations. A. Mount Kanaima (Myersiohyla kanaima); B. Paramakatoi (Hypsiboas sibleszi); C. Mount Ayanganna (Hyla warreni, Hypsiboas lemai, H. roraima, H. sibleszi, Myersiohyla kanaima); D. Mount Roraima (Hyla warreni, Hypsiboas lemai, H. roraima, H. sibleszi, Myersiohyla kanaima); E. La Escalera (Hypsiboas lemai, H. sibleszi); F. Chimantá-tepui (Hypsiboas sibleszi); G. Auyán-tepui (Hypsiboas lemai, $H$. sibleszi).

found only above $1400 \mathrm{~m}$, elsewhere in their range Hypsiboas sibleszi and Myersiohyla kanaima occur at or above 700 and $800 \mathrm{~m}$ respectively. On Roraima and Kanaima, Hypsiboas roraima and Myersiohyla kanaima were found only in montane scrub forest, but at Ayanganna they also occurred in lower montane forest. Hypsiboas sibleszi was found in highcanopy submontane forest at Paramakatoi.

Although Hypsiboas lemai was collected at
1300-1400 m in La Escalera (Rivero 1972 , Duellman 1997), it was found only at $870 \mathrm{~m}$ on Ayanganna, despite intensive collecting at 1400-1500 $\mathrm{m}$. The individuals collected at Ayanganna were part of a chorus of males calling from grassy clumps at the edge of a larger, apparently permanent, fast-flowing stream. Hypsiboas lemai may require permanent stream habitat, as does H. benitezi (Heyer 1994, Myers and Donnelly 1997). 
Reproduction: Many females of Hyla warreni, Hypsiboas roraima, Myersiohyla kanaima and Osteocephalus phasmatus had at least some enlarged ovarian eggs, although none of the Hypsiboas sibleszi females had enlarged eggs. Although no females of Hypsiboas lemai were collected, males were calling. No amplexus was seen in any species. All specimens were collected at the end of the dry season, just before the rainy period that typically occurs in November and December. Because Hyla, Hypsiboas, Myersiohyla and Osteocephalus have aquatic larvae, they are more dependent on seasonally available water than are Stefania, whose reproduction at Mt. Ayanganna appears to be less constrained (MacCulloch and Lathrop 2002).

Both males of Osteocephalus phasmatus have spinous dorsal tubercles and nuptial pads. No calls or other reproductive activities in $O$. phasmatus were noted. All three adult females have enlarged eggs. Presence or absence of subdigital nuptial excrescences and spines on male dorsal tubercles may vary in Osteocephalus, depending on breeding condition (Jungfer and Hödl 2002). These characters, along with many convergent juvenile characters (listed in Jungfer and Hödl 2002), may not be useful characters for distinguishing among species of Osteocephalus.

The only free water on the northeast plateau of Mt. Ayanganna is an intermittent stream, so O. phasmatus may not breed there, but rather in bromeliads, as do some other species of Osteocephalus. Jungfer and Hödl (2002) theorized that species which reproduce in bromeliads have a single subgular vocal sac, adapted to the restrictive leaf-axil breeding and calling site. If $O$. phasmatus does indeed breed in bromeliads, it does not conform to this model.

\section{Acknowledgements}

Specimens were collected and exported under permits issued by the Guyana Environmental Protection Agency. Specimen handling and euthanasia were carried out according to approved animal care protocols. The field assistance of Lancelot George, Roland Edward and especially Carter Cox was greatly appreciated. This study was funded by grants from the Royal Ontario Museum Foundation, the ROM Centre for Biodiversity and Conservation Biology and a Smithsonian BDG Fellowship to RDM. For loans of or access to specimens we thank R. Reynolds, R. McDiarmid, and S. Gotte (USNM), J. Simmons and L. Trueb (KU) and J. Rosado (MCZ). We also thank V. Funk, C. Kelloff, M. Tamessar, D. Naraine, C. Mendonca, and Fr. C.L. Roland. M.A. Donnelly and W.E. Duellman made valuable comments on an earlier version. This is contribution 318 of the Centre for Biodiversity and Conservation Biology, ROM, and number 82 in the Smithsonian's Biological Diversity of the Guiana Shield Program publication series.

\section{References}

Altig, R. and R. W. McDiarmid. 1999. Body plan. Pp. 24-51 in McDiarmid, R.W. and R. Altig (eds.), Tadpoles - the biology of anuran larvae. Chicago. University of Chicago Press.

Ayarzagüena, J., J. C. Señaris and S. Gorzula. 1992a. El grupo Osteocephalus rodriguezi de las tierras altas de la guayana venezolana: descripción de cinco nuevas especies. Memoria de la Sociedad de Ciencias Naturales La Salle 52: 113-142.

Ayarzagüena, J., J. C. Señaris and S. Gorzula. 1992b. Nuevo género para las especies del grupo "Osteocephalus rodriguezi" (Hylidae). Memoria de la Sociedad de Ciencias Naturales La Salle 52: 213221.

Barrio, C. L. 1998. Sistematica y biogeografía de los anfibios (Amphibia) de Venezuela. Acta Biologica Venezuelica 18: 1-93.

Boulenger, G. A. 1900. Batrachians. Pp. 53-56 in Lankester, E.R. Report on a collection made by Messrs. F. V. McConnell and J. J. Quelch at Mount Roraima in British Guiana. Transactions of the Linnaean Society of London, Zoological Series 2, 8 (2).

Crawford, S. C. 1931. II. Field keys to the lizards and amphibians of British Guiana. Annals of the Carnegie Museum 21: 11-42.

Donnelly, M. A. and C. W. Myers. 1991. Herpeto- 
logical results of the 1990 Venezuelan expedition to the summit of Cerro Guaiquinima, with new tepui reptiles. American Museum Novitates 3017: $1-54$.

Duellman, W. E. 1973. Frogs of the Hyla geographica group. Copeia 1973: 515-533.

Duellman, W. E. 1997. Amphibians of La Escalera region, southeastern Venezuela: taxonomy, ecology, and biogeography. Scientific Papers, Natural History Museum, University of Kansas 2: 1-52.

Duellman, W. E. and M. S. Hoogmoed. 1992. Some hylid frogs from the Guiana highlands, northeastern South America: new species, distributional records, and a generic reallocation. Occasional Papers of the Museum of Natural History, University of Kansas 147: 1-21.

Duellman, W. E. and J. Lescure. 1973. Life history and ecology of the hylid frog Osteocephalus taurinus, with observations on larval behaviour. Occasional Papers of the Museum of Natural History, University of Kansas 13: 1-12.

Duellman, W. E. and J. R. Mendelson. 1995. Amphibians and reptiles from northern Departmento Loreto, Peru: taxonomy and biogeography. University of Kansas Science Bulletin 55: 329-376.

Faivovich, J., C. F. B. Haddad, P. C. A. Garcia, D. R. Frost, J. A. Campbell and W. C. Wheeler. 2005. Systematic review of the frog family Hylidae, with special reference to Hylinae: phylogenetic analysis and taxonomic revision. Bulletin of the American Museum of Natural History 294: 1-240.

Goin, C. J. and J. D. Woodley. 1969. A new tree-frog from Guyana. Zoological Journal of the Linnaean Society 48: 135-140.

Gorzula, S. 1992. La herpetofauna del macizo del Chimanta. Pp. 267-280, 304-310 in O. Huber (ed.), El macizo del Chimanta. Caracas. O. Todtmann Editores.

Gorzula, S. and J. C. Señaris. 1996. Una nueva especie del género Osteocephalus (Anura: Hylidae) de la Gran Sabana, Venezuela. Acta Biologica Venezuelica 16: $19-22$.

Gorzula, S. and J. C. Señaris. 1999 (1998). Contribution to the herpetofauna of the Venezuelan Guayana I. A data base. Scientia Guaianae \#8; xviii $+270+$ $32 \mathrm{pp}$.

Gosner, K. L. 1960. A simplified table for staging anuran embryos and larvae with notes on identification. Herpetologica 16: 183-190.

Henle, K. 1981. Hyla elkejungingerae, ein neuer Hylide aus dem peruanischen regenwald (Amphibia: Salientia: Hylidae). Amphibia-Reptilia 2: 123-132.

Heyer, W. R. 1994. Hyla benitezi (Amphibia: Anura:
Hylidae): first record for Brazil and its biogeographical significance. Journal of Herpetology 28: 497-499.

Hoogmoed, M. S. 1979a. The herpetofauna of the Guianian region. Pp. 241-279 in W.E. Duellman (ed.), The South American Herpetofauna: its origin, evolution and dispersal. University of Kansas Mongraph 7.

Hoogmoed, M. S. 1979b. Resurrection of Hyla ornatissima Noble (Amphibia, Hylidae) and remarks on related species of green tree frogs from the Guiana area. Zoologische Verhandelingen 172: 1-46.

Huber, O., G. Gharbarran and V. Funk. 1995. Vegetation Map of Guyana. Georgetown. Centre for the Study of Biological Diversity, University of Guyana.

Jungfer, K. -H. and W. Hödl. 2002. A new species of Osteocephalus from Ecuador and a redescription of O. leprieurii (Dumeril \& Bibron, 1841) (Anura: Hylidae). Amphibia-Reptilia 23: 21-46.

Jungfer, K. -H. and E. Lehr. 2001. A new species of Osteocephalus with bicoloured iris from Pozuzo (Peru: Departamento de Pasco) (Amphibia: Anura: Hylidae). Zoologische Abhandlungen 51: 321-329.

Jungfer, K. -H. and L. C. Schiesari. 1995. Description of a central amazonian and Guianan tree-frog, genus Osteocephalus (Anura, Hylidae), with oophagous tadpoles. Alytes 13: 1-13.

Jungfer, K. -H., S. Ron, R. Seipp, and A. Almendariz. 2000. Two new species of hylid frogs, genus Osteocephalus, from Amazonian Ecuador. Amphibia-Reptilia 21: 327-340.

Lescure, J. 1975. Contribution à l'étude des amphibiens de Guyane française. III. Une nouvelle espèce de Colostethus (Dendrobatidae): Colostethus degranvillei nov. sp. Bulletin du Muséum National d'Histoire Naturelle 3(293), Zoologie 203: 413420 .

Lescure, J. and C. Marty. 2001. Atlas des Amphibiens de Guyane. Paris. Muséum National d'Histoire Naturelle. 388 pp.

Leviton, A. E., R. H. Gibbs, E. Heal, and C. E. Dawson. 1985. Standards in herpetology and ichthyology: Part I. Standard symbolic codes for institutional resource collections in herpetology and ichthyology. Copeia 1985: 802-832.

Lynch, J. D. 2002. A new species of the genus Osteocephalus (Hylidae: Anura) from the western Amazon. Revista de la Academia Colombiana de Ciencias Exactas, Físicas y Naturales 26: 289-292.

MacCulloch, R. D. and A. Lathrop. 2002. Exceptional diversity of Stefania (Anura: Hylidae) on Mount Ayanganna, Guyana: three new species and new distributional records. Herpetologica 58: 327-346. 
Martins, M. and A. J. Cardoso. 1987. Novas especies de hilídeos do estado do Acre (Amphibia: Anura). Revista Brasileira de Biologia 47: 549-558.

Myers, C. W. and M. A. Donnelly. 1996. A new herpetofauna from Cerro Yaví, Venezuela: first results of the Robert G. Goelet American Museum - Terramar expedition to the northwestern tepuis. American Museum Novitates 3172: 1-56.

Myers, C. W. and M. A. Donnelly. 1997. A tepui herpetofauna on a granitic mountain

(Tamacuari) in the borderland between Venezuela and Brazil: report from the Phipps Tapirapecó expedition. American Museum Novitates 3213: 171 .

Myers, C. W. and M. A. Donnelly. 2001. Herpetofauna of the Yutajé-Corocoro massif, Venezuela: second report from the Robert G. Goelet American Museum - Terramar expedition to the northwestern tepuis. Bulletin of the American Museum of Natural History 261: 1-85.

Myers, C. W. and W. E. Duellman. 1982. A new species of Hyla from Cerro Colorado, and other tree frog records and geographical notes from western Panama. American Museum Novitates 2752: 1-32.

Rivero, J. 1972 (1971). Notas sobre los anfibios de Venezuela I. Sobre los hilidos de la guayana venezolana. Caribbean Journal of Science 11: 181-193.

Rodriguez, L. O. and W. E. Duellman. 1994. Guide to the frogs of the Iquitos region, Amazonian Peru. Special Publication of the Museum of Natural History, University of Kansas 22: 1-80.

Ron, S. and J. B. Pramuk. 1999. A new species of Osteocephalus (Anura: Hylidae) from Amazonian Ecuador and Peru. Herpetologica 55: 433-446.

Savage, J. M. and W. R. Heyer. 1997. Digital webbing formulae for amphibians: a refinement. Herpetological Review 28: 131.

Smith, E. N. and B. P. Noonan. 2001. A new species of Osteocephalus (Anura: Hylidae) from Guyana. Revista de Biología Tropical 49: 347-357.

Trueb, L. 1970. The evolutionary relationships of casque-headed treefrogs with co-ossified skulls (family Hylidae). University of Kansas Publications, Museum of Natural History 18: 547-716.

Trueb, L. and W. E. Duellman. 1971. A synopsis of neotropical hylid frogs, genus Osteocephalus. Occasional Papers of the Museum of Natural History, University of Kansas 1: 1-47.

\section{Appendix I - Specimens Examined}

Hyla warreni - GUYANA: District 7: Mt. Ayanganna, 1490-1550 m, ROM 39487-39496.

Hypsiboas benitezi - BRAZIL: Roraima: Vila Pacaraima, USNM 302432-6.

Hypsiboas lemai - GUYANA: District 7: Mt. Ayanganna, 870m, ROM 39567-39571; VENEZUELA: Bolivar: El Dorado-Santa Elena road, km 112, KU 166829-32.

Hypsiboas roraima - GUYANA: District 7: Mt. Ayanganna, 1490-1550 m, ROM 3959639624; 870 m, ROM 39625-7.

Hypsiboas sibleszi - GUYANA: District 7: Mt. Ayanganna, $1550 \mathrm{~m}$, ROM 39552-566; Paramakatoi, 800 m, ROM 28450.

Myersiohyla kanaima - GUYANA: District 7: Mt. Ayanganna, 1490-1550 m, ROM 3927939295; 870 m, ROM 39272-7; Mazaruni-Potaro: Mount Kanaima, USNM 154214, MCZ 51271, KU 182469.

Osteocephalus buckleyi - ECUADOR: Pastaza: Conambo, USNM 166003-4, 166018; VENEZUELA: Amazonas: Brazo Casiquiare, USNM 216682.

Osteocephalus leprieurii - GUYANA: Cuyuni: Kartabo, USNM 118052; PERU: Loreto: Lagarto Cocha, USNM 520974-9; VENEZUELA: Amazonas: Rio Movaca, USNM 216686-9.

Osteocephalus pearsoni - BOLIVIA: Beni: Ballivian, USNM 280593-600.

Osteocephalus planiceps - ECUADOR: Pastaza: Coca, USNM 320881.

Osteocephalus taurinus - FRENCH GUIANA: Cayenne: Sinnamary, USNM 343984; GUYANA: Northwest: Baramita, ROM 22737-9, 22754; Rupununi: Iwokrama Forest Reserve, USNM 531455-74; VENEZUELA: Amazonas: Brazo Casiquiare, USNM 216690; Puerto Ayacucho, USNM 216691-2.

Tepuihyla rodriguezi - VENEZUELA: Bolivar: El Dorado-Sta. Elena road, km 144, KU 166998, 167007, 167010, 167013; Paso del Danto, USNM 166835.

Tepuihyla talbergae - GUYANA: MazaruniPotaro: Kaieteur Falls, USNM 291235-7. 